\title{
Sebaceous Carcinoma of The Lip: Report of a Case and Literature Review.
}

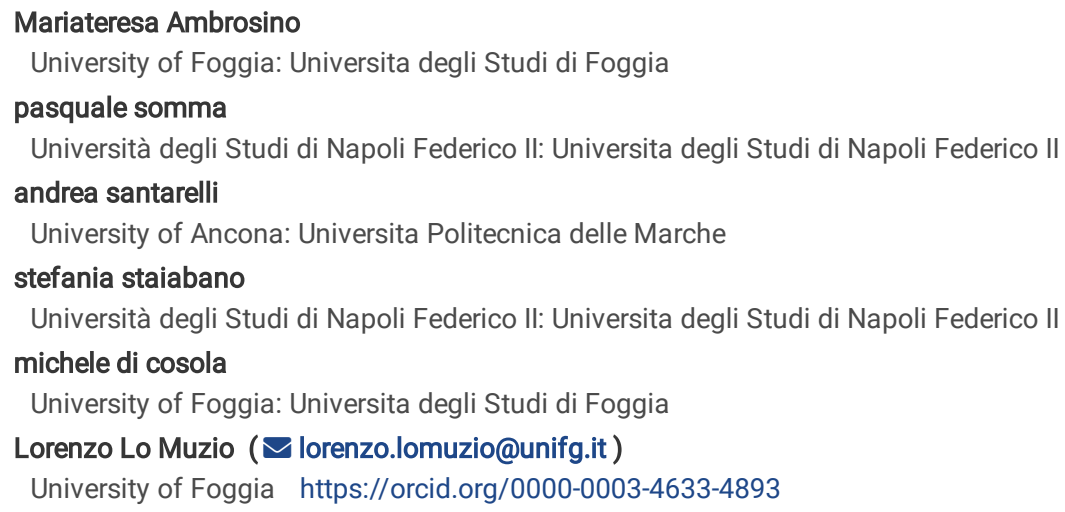

\section{Case report}

Keywords: sebaceous carcinoma, lower lip, immunohistochemistry, case report

Posted Date: August 12th, 2021

DOI: https://doi.org/10.21203/rs.3.rs-776857/v1

License: (c) (1) This work is licensed under a Creative Commons Attribution 4.0 International License. Read Full License 


\section{Abstract \\ Background}

Sebaceous carcinoma (SC) is a very rare, aggressive, malignant tumor arising in the adnexal epithelium of the sebaceous gland. SC in the oral cavity is extremely rare, in literature there are only 14 cases. We reported the 4 th case of sebaceous carcinoma involving the lip

\section{Case presentation}

A 71-year-old male smoker presented an ulcerated lesion in the lateral region of the lower lip. The patient stated that the lesion had been present for 1 year. The past medical history was unremarkable. Extra-oral examination revealed a markedly ulcerated, exophytic, irregularly shaped, indurated mass of the lower right labial region, measuring $1.8 \mathrm{~cm}$ in size. The nodular lesion, located at the point of transition between mucosa and skin, showed a central ulceration. No other intraoral lesions were identified. The clinical differential diagnosis included squamous cell carcinoma, basal cell carcinoma with sebaceous differentiation and salivary gland neoplasms. The operation was performed under local anaesthesia. On histopathological examination, the tumor was composed by nodules or sheet of cells separated by a fibrovascolar stroma. The neoplastic tissue was deeply infiltrating, involving the submucosa and even the underlying muscle. Neoplastic cells showed a range of sebaceous differentiation with finely vacuolated rather than clear cytoplasm. Neoplastic cells were positive for S-100 protein, EMA, but negative for CEA. Therefore, based on these findings, a diagnosis of sebaceous carcinoma of the lower lip was rendered.

\section{Conclusion}

The histogenesis, differential diagnosis, and clinicopathologic conditions of this disease in the literature were reviewed. SC should be distinguished from other tumors full of vacuolated clear cells. Some useful biomarkers can be Ki-67, P53, CK, PAS, S-100, EMA, and AR.

\section{Introduction}

Sebaceous carcinoma (SC) is a rare neoplasm. To date fewer than 400 cases have been reported in literature. Due to the low incidence and the not universally accepted histopathological classification, it can present diagnostic problems (1). Generally, the lesions arise in the meibomian glands of the eyelid. However, extra-ocular localization in the head and neck region have been reported (1-3). The salivary glands too are considered an uncommon site, even if some cases arising in the parotid gland were recognized (4). While several reports documented sebaceous adenomas arising from sebaceous glands of the oral cavity, oral sebaceous carcinomas are extremely rare.

Sebaceous glands in the oral mucosa are widely found in approximately $80 \%$ of adults and are called Fordyce granules $(5,6)$. Due to the high incidence rate, Fordyce granules are considered a normal anatomic variation $(5,6)$. These granules appear as small asymptomatic yellow-white papules or granules in the oral mucosa. It seems that these intraoral sebaceous glands rarely give rise to a variety of sebaceous neoplasms, such as sebaceous carcinoma(7). From 1991 when Damm et al. described the first known report in the English-language literature of a sebaceous carcinoma presenting as an intraoral tumor(8), only 14 cases have been described (Table 1$)(2,3,7-18)$. 
Table 1

Reported cases of primary intraoral sebaceous carcinoma

\begin{tabular}{|c|c|c|c|c|c|c|c|c|c|c|c|c|}
\hline & Authors & Year & Country & Sex & Age & Smoker & Site & Size & Case & $\begin{array}{l}\text { Tumor involving } \\
\text { other structures }\end{array}$ & Treatment & $\begin{array}{l}\text { Follo' } \\
\text { up } \\
\text { years }\end{array}$ \\
\hline 1. & $\begin{array}{l}\text { Damm et } \\
\text { al.(8) }\end{array}$ & 1991 & USA & M & 53 & Unknown & $\begin{array}{l}\text { Buccal } \\
\text { mucosa } \\
\text { (parotid } \\
\text { duct) }\end{array}$ & 3 & $\begin{array}{l}\text { intraoral } \\
\text { sebaceous } \\
\text { carcinoma }\end{array}$ & no & Excision & 5 \\
\hline 2. & $\begin{array}{l}\text { Abuzeid et } \\
\text { al.(9) }\end{array}$ & 1996 & $\begin{array}{l}\text { Saudi } \\
\text { Arabia }\end{array}$ & $\mathrm{F}$ & 11 & No & $\begin{array}{l}\text { Buccal } \\
\text { mucosa }\end{array}$ & 3 & $\begin{array}{l}\text { intraoral } \\
\text { sebaceous } \\
\text { carcinoma }\end{array}$ & $\begin{array}{l}\text { submandibular } \\
\text { salivary gland,2 } \\
\text { lymph nodes }\end{array}$ & Excision & 2 \\
\hline 3. & $\begin{array}{l}\text { Liu et al. } \\
(10)\end{array}$ & 1997 & Taiwan & M & 68 & Unknown & $\begin{array}{l}\text { Buccal } \\
\text { mucosa }\end{array}$ & 2,5 & $\begin{array}{l}\text { Sebaceous } \\
\text { carcinoma } \\
\text { of buccal } \\
\text { mucosa. }\end{array}$ & no & Excision & 3 \\
\hline 4. & $\begin{array}{l}\text { Li et al. } \\
(11)\end{array}$ & 1997 & Japan & M & 78 & Yes & $\begin{array}{l}\text { Buccal } \\
\text { mucosa }\end{array}$ & 3.5 & $\begin{array}{l}\text { oral } \\
\text { sebaceous } \\
\text { carcinoma }\end{array}$ & Surrounding muscle & Excision & 6 \\
\hline 5. & $\begin{array}{l}\text { Handschel } \\
\text { et al.(3) }\end{array}$ & 2003 & Germany & $\mathrm{F}$ & 80 & No & $\begin{array}{l}\text { Anterior } \\
\text { floor of } \\
\text { the } \\
\text { mouth }\end{array}$ & 1.5 & $\begin{array}{l}\text { intraoral } \\
\text { sebaceous } \\
\text { carcinoma }\end{array}$ & no & Excision & 1 \\
\hline 6. & $\begin{array}{l}\text { Alawi et } \\
\text { al.(2) }\end{array}$ & 2005 & USA & M & 66 & Yes & Upper lip & 1,5 & $\begin{array}{l}\text { Sebaceous } \\
\text { carcinoma } \\
\text { of the oral } \\
\text { mucosa }\end{array}$ & no & Excision & 1 \\
\hline 7. & $\begin{array}{l}\text { Innocenzi } \\
\text { et al.(12) }\end{array}$ & 2005 & Italy & $\mathrm{F}$ & 68 & no & Upper lip & 2 & $\begin{array}{l}\text { Sebaceous } \\
\text { carcinoma }\end{array}$ & no & excision & 3 \\
\hline 8. & $\begin{array}{l}\text { Gomes et } \\
\text { al.(13) }\end{array}$ & 2007 & Brazil & $M$ & 55 & yes & $\begin{array}{l}\text { Floor of } \\
\text { mouth }\end{array}$ & $\begin{array}{l}\text { Not } \\
\text { reported }\end{array}$ & $\begin{array}{l}\text { Intraoral } \\
\text { sebaceous } \\
\text { carcinoma }\end{array}$ & $\begin{array}{l}\text { mandible body and } \\
\text { ramus, masseter } \\
\text { muscle }\end{array}$ & $\begin{array}{l}\text { Excision, } \\
\text { chemotherapy, } \\
\text { radiotherapy }\end{array}$ & 1 \\
\hline 9. & $\begin{array}{l}\text { Wang et } \\
\text { al.(14) }\end{array}$ & 2010 & USA & M & 50 & no & $\begin{array}{l}\text { Buccal } \\
\text { mucosa }\end{array}$ & 4.6 & $\begin{array}{l}\text { Sebaceous } \\
\text { carcinoma } \\
\text { of the oral } \\
\text { cavity }\end{array}$ & no & $\begin{array}{l}\text { Excision + } \\
\text { radiation } \\
\text { therapy }\end{array}$ & $<1$ \\
\hline 10. & $\begin{array}{l}\text { Oshiro et } \\
\text { al.(15) }\end{array}$ & 2010 & Japan & M & 66 & unknown & $\begin{array}{l}\text { Tongue } \\
\text { and } \\
\text { dorsum }\end{array}$ & 2.5 & $\begin{array}{l}\text { Primary } \\
\text { sebaceous } \\
\text { carcinoma } \\
\text { of the } \\
\text { tongue }\end{array}$ & $\begin{array}{l}\text { cervical lymph nodes } \\
\text { bilaterally, lung }\end{array}$ & $\begin{array}{l}\text { Intra-arterial } \\
\text { chemotherapy/ } \\
\text { radiation }\end{array}$ & $\begin{array}{l}\text { Died } \\
\text { after } \\
\text { mont }\end{array}$ \\
\hline 11. & $\begin{array}{l}\text { Rowe et } \\
\text { al.(16) }\end{array}$ & 2016 & USA & $M$ & 76 & yes & $\begin{array}{l}\text { Anterior } \\
\text { maxillary } \\
\text { gingiva }\end{array}$ & 3 & $\begin{array}{l}\text { intraoral } \\
\text { sebaceous } \\
\text { carcinoma } \\
\text { metastatic } \\
\text { to the lung } \\
\text { and } \\
\text { subcutis }\end{array}$ & $\begin{array}{l}\text { Skin of } \\
\text { thigh/buttocks/lungs }\end{array}$ & $\begin{array}{l}\text { Excision }+ \\
\text { chemotherapy }\end{array}$ & $<1$ \\
\hline 12. & $\begin{array}{l}\text { Greenall et } \\
\text { al.(17) }\end{array}$ & 2015 & UK & $M$ & 81 & unknown & $\begin{array}{l}\text { Right } \\
\text { upper lip }\end{array}$ & $\begin{array}{l}\text { Not } \\
\text { reported }\end{array}$ & $\begin{array}{l}\text { sebaceous } \\
\text { carcinoma }\end{array}$ & $\begin{array}{l}\text { soft tissues of the } \\
\text { right upper lip, } \\
\text { buccal space, } \\
\text { retromolar trigone } \\
\text { (Fig. 2), } \\
\text { pterygopalatine } \\
\text { fossa and apex of } \\
\text { the infratemporal } \\
\text { fossa }\end{array}$ & $\begin{array}{l}\text { Palliative } \\
\text { radiotherapy }\end{array}$ & $\begin{array}{l}\text { Not } \\
\text { repor }\end{array}$ \\
\hline 13. & $\begin{array}{l}\text { Wetzel et } \\
\text { al.(18) }\end{array}$ & 2015 & USA & $M$ & 75 & Yes & $\begin{array}{l}\text { Maxillary } \\
\text { gingiva }\end{array}$ & $\begin{array}{l}\text { Not } \\
\text { reported }\end{array}$ & $\begin{array}{l}\text { Sebaceous } \\
\text { carcinoma }\end{array}$ & no & Excision & $\begin{array}{l}\text { Not } \\
\text { repor }\end{array}$ \\
\hline 14. & $\begin{array}{l}\text { Lu et al. } \\
\text { (7) }\end{array}$ & 2021 & China & $\mathrm{F}$ & 62 & Unknown & $\begin{array}{l}\text { Soft } \\
\text { palate }\end{array}$ & 2 & $\begin{array}{l}\text { intraoral } \\
\text { sebaceous } \\
\text { carcinoma }\end{array}$ & no & excision & $\begin{array}{l}\text { Not } \\
\text { repor }\end{array}$ \\
\hline 15. & $\begin{array}{l}\text { Present } \\
\text { case }\end{array}$ & 2021 & Italy & $M$ & 71 & yes & lip & 1,8 & $\begin{array}{l}\text { sebaceous } \\
\text { carcinoma }\end{array}$ & no & excision & 3 \\
\hline
\end{tabular}

Regardless of the localization, sebaceous malignancies must be considered aggressive neoplasms with a potential for regional and distant metastases. The treatment of this tumor points to a wide surgical excision with safe margins. Eventually implicated regional lymph nodes have to be excised too (19, 20).

Disagreement still exists concerning the efficacy of post-surgical irradiation and/or chemotherapy $(1,19,20)$. 
Herein we reported a case of SC arising in the lateral edge of the lower lip in a 71-year-old men. To the best of our knowledge this is the fourth case described in lips.

\section{Case Report}

A 71-year-old male smoker presented an ulcerated lesion in the lateral region of the lower lip (Fig. 1). The patient stated that the lesion had been present for 1 year. No previous trauma in face or mouth was recalled. The past medical history was unremarkable. Extra-oral examination revealed a markedly ulcerated, exophytic, irregularly shaped, indurated mass of the lower right labial region, measuring $1.8 \mathrm{~cm}$ in size. The nodular lesion, located at the point of transition between mucosa and skin, showed a central ulceration. No other intraoral lesions were identified.

On palpation, the neck was soft with full range of motion and there was no evidence of lymphadenopathy or tenderness. The patient was in good health and had no evidence of disease.

The clinical differential diagnosis included squamous cell carcinoma, basal cell carcinoma with sebaceous differentiation (BCCSD) and salivary gland neoplasms.

The operation was performed under local anaesthesia. The lesion was removed with $0.5 \mathrm{~cm}$ of free margins and a W shaped wedge. The defect was primarily closed. The post-operative course was uneventful.

Four-micron thickness serial sections were obtained from formalin-fixed, paraffin-embedded surgical specimen. One section was stained with haematoxylineosin. Immunohistochemistry was performed on the remaining serial sections using the labelled streptavidin-biotin complex system (DAKO) for the study of the expression of epithelial membrane antigen (EMA), S-100 protein and carcino-embryonic antigen (CEA), using the following primary antibodies: anti-EMA (057 M Biogenex; 1:100), anti-S100 (058 P Biogenex; 1:100), and anti- CEA (365 M Biogenex; 1:100).

On histopathological examination, the tumor was composed by nodules or sheet of cells separated by a fibrovascolar stroma. The neoplastic tissue was deeply infiltrating, involving the submucosa and even the underlying muscle (Fig. 2A). Neoplastic cells showed a range of sebaceous differentiation with finely vacuolated rather than clear cytoplasm. Also areas with squamous differentiation were present. Large nuclei with large nucleoli, as well as scattered and atypical mitoses were observed (Fig. 2B). Neoplastic cells were positive for S-100 protein (Fig. 2C), EMA (Fig. 2D), but negative for CEA. Therefore, based on these findings, a diagnosis of sebaceous carcinoma of the lower lip was rendered. Following the diagnosis, the patient underwent a complete clinical and radiographic evaluation in order to identify any regional or distant metastases. Because no metastases were detected, no further treatments were deemed necessary.

\section{Discussion}

Glands with sebaceous differentiation are often found in the oral cavity, and sebaceous differentiation may also be detected in the major salivary glands. Nevertheless, SC is rare in these anatomic sites $(3,21)$. Sebaceous glands may be present in the lip, as described by Miles $(21)$. Data from the literature indicate that extraocular sebaceous carcinomas are less aggressive than orbital ones. Furthermore, the former rarely metastasised (19). However a recent study, involving 2422 cases of SC over 10 years, showed that among extraocular head and neck SC cases, none of the orbital tumor metastasised to the locoregional lymph nodes whereas two of the five cases of the extraocular SC metastasised to the locoregional lymph nodes (20).

A comprehensive literature review identified only 15 cases of intraoral SC, of which the primary sites reported were the buccal mucosa, mouth floor, upper labial mucosa, palate, gingiva and tongue. The majority of cases of SC occur on the buccal mucosa: $5 / 15(22.22 \%)$. Other sites include the labial mucosa with $4 / 15(26 \%)$, anterior floor of mouth with $2 / 15(13 \%)$, gingiva with $2 / 15(13 \%)$, palate with $1 / 15(7 \%)$ and tongue with $1 / 15(7 \%)$. To the best of the our knowledge this is the fourth case of SC of the lip described in literature. $11 / 15$ were men (73.3\%) and $4 / 15$ women (26.7\%). The age ranged from to 11 to 81 years old (mean 64 years old). The reported size of 12 lesions ranged from $1.5 \mathrm{~cm}$ to $4.6 \mathrm{~cm}$ (mean $2.55 \mathrm{~cm}$ ). $6 / 15$ cases (40\%) showed the involvement of contiguous sites or the presence of metastasis to lymph nodes or to lung. Data about smoking seem to be very interesting: $6 / 10$ were smokers (60\%).

Although SC may be found among the multiple sebaceous neoplasms occurring in association with multiple visceral carcinomas in the Muir-Torre syndrome (22), in the present case the lip was the only localization of SC.

SC must be distinguished from basal cell carcinoma with sebaceous differentiation (BCCSD). Basal cell carcinoma is characterized by a superficial plate-like proliferation of basaloid and/or squamoid cells with broad attachments to the overlying epidermis. The cells did not show high cytological atypia or atypical mitoses. Clusters of mature cells are abruptly interposed among otherwise typical basaloid cell nests, without transitional form (23, 24). However, differential diagnosis could be particularly difficult because areas of sebaceous differentiation may have similar distribution in both lesions (25). As in the present case, the involvement of epidermis or dermis favours the diagnosis of SC. Unfortunately it is not invariably present (25).

The diagnosis may be facilitated by lipophylic stains on frozen sections or immune-stains for EMA and S-100. While SC results diffusely positive for both previously mentioned antibodies, BCCSD show reactivity only in areas with evident sebaceous differentiation (26-29). SC have to be differentiated also from the squamous cell carcinoma (SCC) with hydropic degeneration. However, the latter show a different pattern of growth. Moreover, cytological atypia and atypical mitoses are more evident and neoplastic cells are positive for cytokeratin and EMA, but negative for S-100 $(26,29)$.

Like other extremely rare neoplasms, the optimal treatment of SC is not fully conclusive. The therapeutic options range from wide excision to pre- and postoperative radiotherapy with or without chemotherapy (26). In our case a wide excision of the lesion was performed without other post-operative therapy. The patient is alive without evidence of recurrence or metastases after 36 months of follow-up. 


\section{Conclusion}

A rare case of SC in a patient's lip was observed. Radical surgery was carried out. The histogenesis, differential diagnosis, and clinicopathologic conditions of this disease in the literature were reviewed. SC should be distinguished from other tumors full of vacuolated clear cells. Useful biomarkers can be Ki-67, P53, CK, PAS, S-100, EMA, and AR in order to help verify the diagnosis. Postoperative chemotherapy and radiotherapy were not adopted in the present case, as the postoperative pathology showed negative tumor margins, and there was no evidence of lymph node metastasis, the patient was relatively satisfied with the surgery.

\section{Declarations}

\section{Funding}

This research did not receive any specific grant from funding agencies in the public, commercial, or not-for-profit sectors.

\section{Ethics approval and consent to participate}

Not required by the relevant ethics committee. Patient signed informed consent form for the treatment provided.

\section{Consent for publication}

Written informed consent has been obtained from the patient to publish this paper.

\section{Availability of data and materials}

Not applicable

\section{Competing interests}

The authors declare that they have no competing interests

\section{Funding}

Not applicable

\section{Authors' contributions}

AM and LLM reviewed the literature and contributed to manuscript drafting; SA reviewed the literature and contributed to manuscript drafting; SS and SP performed pathological analyses and interpretation and contributed to manuscript drafting; DCM performed reviewed the literature and drafted the manuscript; all authors issued final approval for the version to be submitted.

\section{Acknowledgements}

Not applicable

\section{Authors' information}

\section{Affiliations}

Department of Clinical and Experimental Medicine, University of Foggia, 71122 Foggia, Italy. Mariateresa Ambrosino, Michele Di Cosola, Lorenzo Lo Muzio

Department of Biomorphological and Functional Sciences, University of Naples “Federico II", 80121 Naples, Italy. Pasquale Somma, Stefania Staibano

Dipartimento di Scienze Cliniche Specialistiche e Odontostomatologiche, Università Politecnica delle Marche, 60121 Ancona, Italy. Andrea Santarelli

\section{References}

1. Bailet JW, Zimmerman MC, Arnstein DP, Wollman JS, Mickel RA. Sebaceous carcinoma of the head and neck. Case report and literature review. Arch Otolaryngol Head Neck Surg. 1992;118(11):1245-9.

2. Alawi F, Siddiqui A. Sebaceous carcinoma of the oral mucosa: case report and review of the literature. Oral Surg Oral Med Oral Pathol Oral Radiol Endod. 2005;99(1):79-84.

3. Handschel J, Herbst H, Brand B, Meyer U, Piffko J. Intraoral sebaceous carcinoma. Br J Oral Maxillofac Surg. 2003;41(2):84-7.

4. Esnal Leal F, Garcia-Rostan y Perez GM, Garatea Crelgo J, Gorriaran Terreros M. Arzoz Sainz de Murieta E. [Sebaceous carcinoma of salivary gland. Report of two cases of infrequent location]. An Otorrinolaringol Ibero Am. 1997;24(4):401-13.

5. Halperin V, Kolas S, Jefferis KR, Huddleston So, Robinson HB. The occurrence of Fordyce spots, benign migratory glossitis, median rhomboid glossitis, and fissured tongue in 2,478 dental patients. Oral Surg Oral Med Oral Pathol. 1953;6(9):1072-7.

6. Miles AE. Sebaceous glands in the lip and cheek mucosa of a man. Br Dent J. 1958;105:235-48.

7. Lu Q, Fu XY, Huang Y. Sebaceous carcinoma of the right palate: case report and literature review. Gland Surg. 2021;10(5):1819-25. 
8. Damm DD, O'Connor WN, White DK, Drummond JF, Morrow LW, Kenady DE. Intraoral sebaceous carcinoma. Oral Surg Oral Med Oral Pathol. 1991;72(6):709-11.

9. Abuzeid M, Gangopadhyay K, Rayappa CS, Antonios JI. Intraoral sebaceous carcinoma. J Laryngol Otol. 1996;110(5):500-2.

10. Liu CJ, Chang KW, Chang RC. Sebaceous carcinoma of buccal mucosa. Report of a case. Int J Oral Maxillofac Surg. 1997;26(4):293-4.

11. Li TJ, Kitano M, Mukai H, Yamashita S. Oral sebaceous carcinoma: report of a case. J Oral Maxillofac Surg. 1997;55(7):751-4.

12. Innocenzi D, Balzani A, Lupi F, Panetta C, Skroza N, Cantoresi F, et al. Morpheaform extra-ocular sebaceous carcinoma. J Surg Oncol. 2005;92(4):344-6.

13. Gomes CC, Lacerda JC, Pimenta FJ, do Carmo MA, Gomez RS. Intraoral sebaceous carcinoma. Eur Arch Otorhinolaryngol. 2007;264(7):829-32.

14. Wang H, Yao J, Solomon M, Axiotis CA. Sebaceous carcinoma of the oral cavity: a case report and review of the literature. Oral Surg Oral Med Oral Pathol Oral Radiol Endod. 2010;110(2):e37-40.

15. Oshiro H, Iwai T, Hirota M, Mitsudo K, Tohnai I, Minamimoto R, et al. Primary sebaceous carcinoma of the tongue. Med Mol Morphol. 2010;43(4):246-52.

16. Rowe ME, Khorsandi AS, Urken GR, Wenig BM. Intraoral sebaceous carcinoma metastatic to the lung and subcutis: Case report and discussion of the literature. Head Neck. 2016;38(1):E20-4.

17. Greenall CJ, Drage NA. Sebaceous carcinoma of the lip: Comparing normal lip and cheek anatomy with the imaging features of a rare cutaneous malignancy. Ultrasound. 2015;23(2):126-9.

18. Wetzel S, Pacelli P, Reich R, Freedman P. Sebaceous carcinoma of the maxillary gingival: First reported case involving the gingiva. Oral Surg Oral Med Oral Pathol Oral Radiol. 2015;120(1):e1-3.

19. Duman DG, Ceyhan BB, Celikel T, Ahiskali R, Duman D. Extraorbital sebaceous carcinoma with rapidly developing visceral metastases. Dermatol Surg. 2003;29(9):987-9.

20. Bassetto F, Baraziol R, Sottosanti MV, Scarpa C, Montesco M. Biological behavior of the sebaceous carcinoma of the head. Dermatol Surg. 2004;30(3):472-6.

21. Miles AEW. Sebaceous Glands in the lip and cheek mucosa of man. Br Dent J. 1958;105:235-48.

22. Elder D, Elenitas R, Ragsdale BD. Tumors of the Epidermal Appendance. Lever's Histopathology of the Skin. 8 ed. Philadelphia: Lippincott; 1997. pp. 7689.

23. Friedman KJ, Boudreau S, Farmer ER. Superficial epithelioma with sebaceous differentiation. J Cutan Pathol. 1987;14(4):193-7.

24. Lee MJ, Kim YC, Lew W. A case of superficial epithelioma with sebaceous differentiation. Yonsei Med J. 2003;44(2):347-50.

25. Wolfe JTI, Wick MR, Campbell RJ. Sebaceous carcinoma of the oculocutaneuos adnexa and extraocular skin. In: Wick MR, editor. Pathology of Unusual Malignant Cutaneous Tumors. New York: Marcel Dekker; 1985. pp. 77-106.

26. Rulon DB, Helwig EB. Cutaneous sebaceous neoplasms. Cancer. 1974;33(1):82-102.

27. Ohara N, Taguchi K, Yamamoto M, Nagano T, Akagi T. Sebaceous carcinoma of the submandibular gland with high-grade malignancy: report of a case. Pathol Int. 1998;48(4):287-91.

28. Ansai S, Hashimoto H, Aoki T, Hozumi Y, Aso K. A histochemical and immunohistochemical study of extra-ocular sebaceous carcinoma. Histopathology. 1993;22(2):127-33.

29. Siriwardena BS, Tilakaratne WM, Rajapakshe RM. A case of sebaceous carcinoma of the parotid gland. J Oral Pathol Med. 2003;32(2):121-3.

\section{Figures}




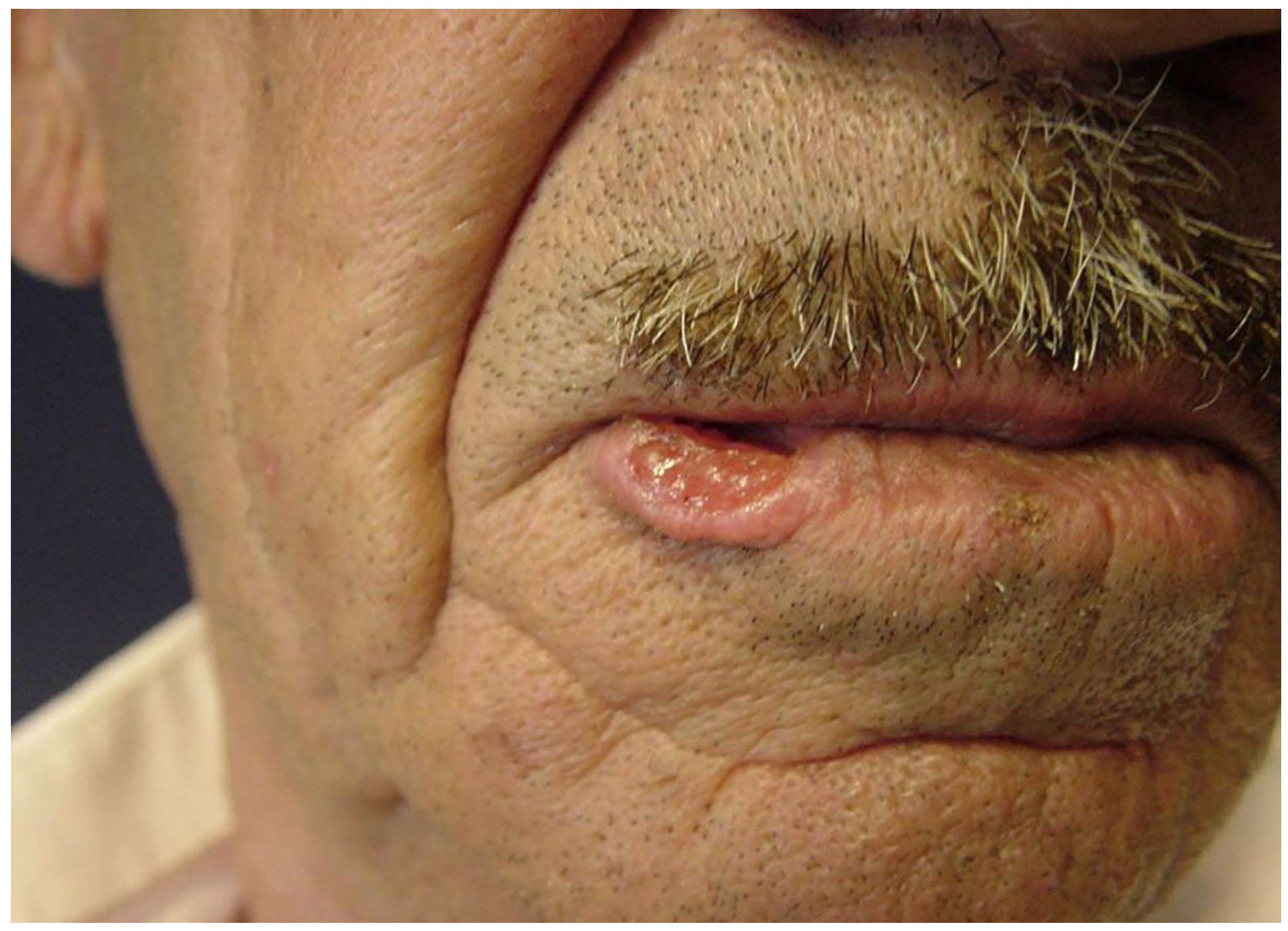

Figure 1

Clinical features of the lesion before the surgical treatment. 

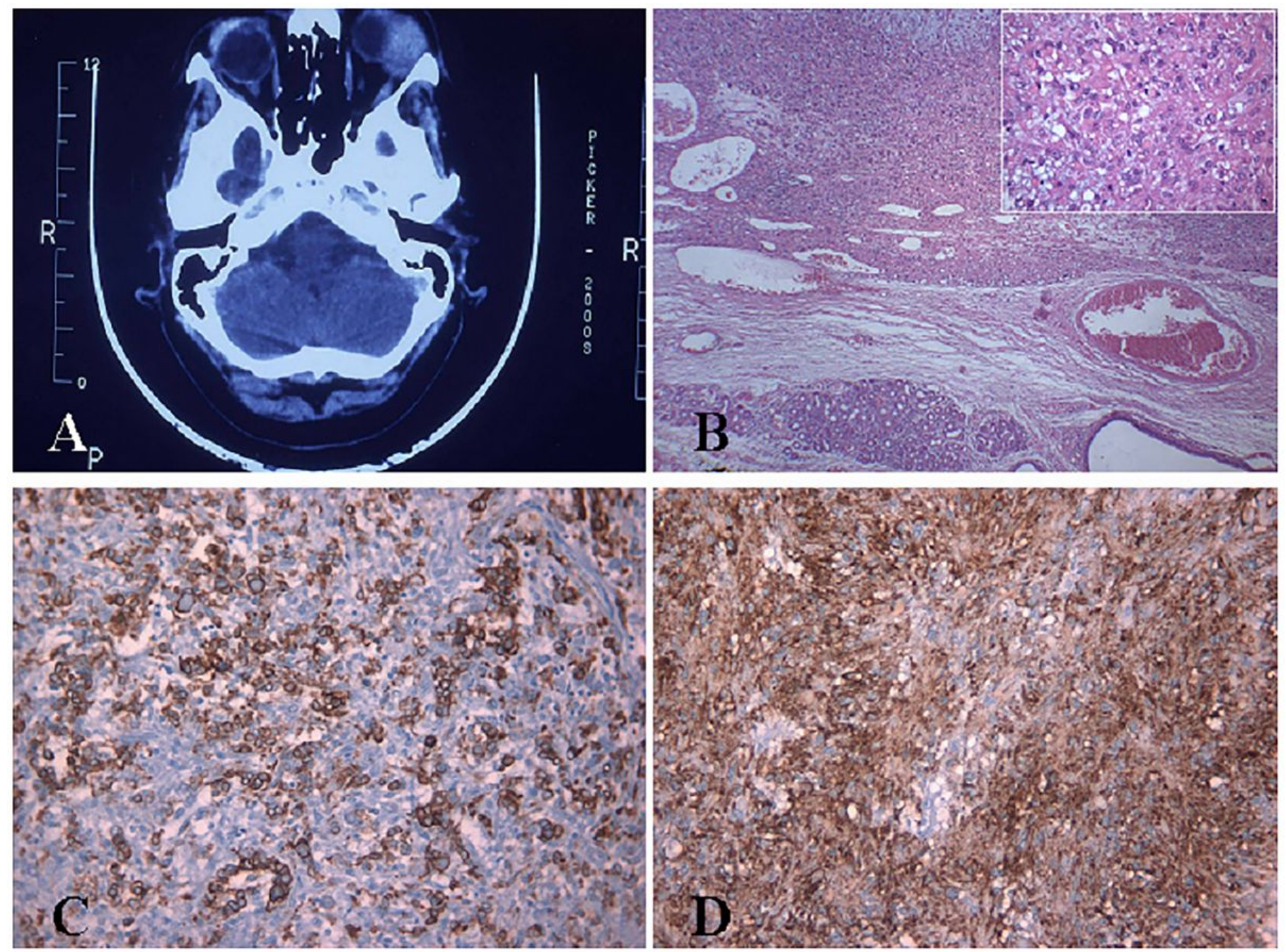

Figure 2

A) Submucosal sebaceous carcinoma showing an infiltrative pattern (E\&E x40); B) Nests of atypical clear cells with scattering squamous differentiation (E\&Ex400); C) The neoplastic cells were positive for S-100 (ABC x200); D) The neoplastic cells were positive for EMA (ABC x200) 